\title{
A decade of marketing approval of gene and cell-based therapies in the United States, European Union and Japan: An evaluation of regulatory decision-making
}

\author{
D.G.M. COPPENS ${ }^{1, \star}$, S. DE WILDE ${ }^{2, \star}$, H.J. GUCHELAAR ${ }^{2,3}$, M.L. DE BRUIN ${ }^{1,4}$, \\ H.G.M. LEUFKENS ${ }^{1}$, P. MEIJ ${ }^{2} \&$ J. HOEKMAN ${ }^{5}$
}

${ }^{1}$ Utrecht Institute for Pharmaceutical Sciences, Utrecht University, Utrecht, The Netherlands, ${ }^{2}$ Department of Clinical Pharmacy \& Toxicology, Leiden University Medical Center, Leiden, The Netherlands, ${ }^{3}$ Dutch Medicines Evaluation Board, Utrecht, The Netherlands, ${ }^{4}$ Copenhagen Centre for Regulatory Science, University of Copenhagen, Copenhagen, Denmark, and ${ }^{5}$ Innovation Studies Group, faculty of Geosciences, Utrecht University, Utrecht, The Netherlands

\begin{abstract}
There is a widely held expectation of clinical advance with the development of gene and cell-based therapies (GCTs). Yet, establishing benefits and risks is highly uncertain. We examine differences in decision-making for GCT approval between jurisdictions by comparing regulatory assessment procedures in the United States (US), European Union (EU) and Japan. A cohort of 18 assessment procedures was analyzed by comparing product characteristics, evidentiary and non-evidentiary factors considered for approval and post-marketing risk management. Product characteristics are very heterogeneous and only three products are marketed in multiple jurisdictions. Almost half of all approved GCTs received an orphan designation. Overall, confirmatory evidence or indications of clinical benefit were evident in US and EU applications, whereas in Japan approval was solely granted based on non-confirmatory evidence. Due to scientific uncertainties and safety risks, substantial post-marketing risk management activities were requested in the EU and Japan. EU and Japanese authorities often took unmet medical needs into consideration in decision-making for approval. These observations underline the effects of implemented legislation in these two jurisdictions that facilitate an adaptive approach to licensing. In the US, the recent assessments of two chimeric antigen receptor-T cell (CAR-T) products are suggestive of a trend toward a more permissive approach for GCT approval under recent reforms, in contrast to a more binary decision-making approach for previous approvals. It indicates that all three regulatory agencies are currently willing to take risks by approving GCTs with scientific uncertainties and safety risks, urging them to pay accurate attention to post-marketing risk management.
\end{abstract}

Key Words: adaptive pathways, benefit/risk assessment, chimeric antigen receptor-T cell, drug regulatory science, expedited pathways, gene and cell-based therapies, life cycle approach, marketing approval, orphan drug designation, post-marketing risk management

\section{Introduction}

Gene and cell-based therapies (GCTs) represent a heterogeneous class of medicines [1-4] with potential for clinical benefit in a wide range of therapeutic areas, including areas with limited treatment availability [5]. Regulatory authorities face considerably uncertainties when deciding on the marketing approval of these products. Quality control and methodologies to demonstrate benefits and risks tend to be suboptimal or not available at all due to the complex and idiosyn- cratic nature of therapies and often small target populations [5-7]. Furthermore, efficacy of novel modes of action and associated potential safety risks (e.g., insertional mutagenesis, tumorigenicity) are uncertain $[1,2,4]$.

Worldwide, regulatory authorities aim to consider benefits and risks in a structured assessment for approval of medicines [8]. However, authorities differ in how they balance the need for robust scientific evidence and timely access for patients [9], as well as to which degree they consider non-evidentiary

^Authors contributed equally.

Correspondence: Jarno Hoekman, PhD, Utrecht University, P.O. Box 80082, Utrecht 3508 TB, The Netherlands. E-mail: j.hoekman@uu.nl 
factors in assessments [10-12]. Due to the novelty of the GCT field, regulators also face scientific issues that have not been discussed in previous regulatory procedures. Consequently, detailed regulatory requirements for GCT approval are not standardized or harmonized yet [13].

So far, insights into regulatory assessment and decision-making for GCT approval are limited, but we observed that the European Union (EU) authorities are currently exploring an adaptive regulatory approach. Furthermore, the regulatory assessment of the first approved gene therapy in the EU was a challenging process due to many scientific uncertainties [14]. However, it is unknown how this approach compares with decision-making for GCT approval in other regions.

This study aimed to compare decision-making for GCT approval by the United States (US), Japanese and EU regulatory authorities during the last 10 years. First, we compared product profiles, evidentiary support and regulatory procedures between jurisdictions. Second, we provided insight into benefit/risk assessments by analyzing how different authorities consider scientific evidence and related uncertainties, plus other non-evidentiary factors to grant approval. Finally, we examined how uncertainties and safety risks are managed post-marketing.

\section{Methods}

This is a cohort study of approved GCTs by the Food and Drug Administration (FDA), Pharmaceuticals and Medical Device Agency (PMDA) and European Medicines Agency (EMA). Data on assessment and decisionmaking for approval were extracted from public assessment reports [15-17]. Assessment procedures were included if (i) GCTs were assessed as a medicine and approved in the last 10 years (2008-2017) and (ii) quality, pre-clinical and clinical evidence were required for application and available for analysis.

\section{Characteristics of regulatory assessments}

We constructed variables to unpack assessment procedures into factors that were part of decisionmaking, such as scientific evidence, medical context and available regulatory processes $[11,12]$. We first defined a preliminary set of variables, building on previous studies [18-20]. We subsequently added other relevant variables to tailor the classification scheme to GCT technological aspects and to adequately capture quality and pre-clinical aspects. Variables were organized under four main categories: (i) product profile, (ii) scientific evidence, (iii) regulatory processes and (iv) outcome. Two researchers (D.C., S.dW.) independently extracted data from assessment reports and assigned pre-determined categorical or numerical values per variable (Supplemental Table S1). Data extraction and value assignment were compared between researchers; discrepancies were discussed until consensus.

We first conducted a quantitative descriptive cohort analysis (analysis 1) based on the assigned values. IBM SPSS Statistics 24 was used to stratify and tabulate data by jurisdiction (Supplemental Table S2). To reveal commonalities between jurisdictions, data was also stratified by orphan drug designation (yes/no) and regulatory pathway for approval (standard/non-standard). Given the small numbers, statistical analysis was not performed.

\section{Benefit/risk assessments and post-marketing risk management}

We subsequently conducted a qualitative analysis to understand evidentiary considerations and other nonevidentiary factors that were decisive for approval (analysis 2), and how uncertainties and safety risks were managed post-marketing (analysis 3 ). We extracted sections on benefit/risk balances and post-marketing obligations from assessment reports. No major discrepancies between specificity, the level of detail and format of EU, Japanese and US assessment reports were identified.

The extracted text was qualitatively analyzed in NVivo Pro 11 for each assessment separately. Evidentiary certainties and uncertainties plus nonevidentiary factors were identified and grouped using the variables. If available, corresponding regulatory interpretation (e.g., satisfactory, unacceptable) and/or post-marketing obligations were identified. Independent data extraction and organization were compared between researchers (D.C., S.dW.). Discrepancies were discussed until consensus.

Four subcategories were frequently part of benefit/ risk assessments: clinical study design, benefits, risks and unmet medical needs. Per subcategory, evidentiary certainties and uncertainties plus regulatory interpretation were captured to illustrate considerations for approval and their relative weight. In addition, post-marketing study obligations demonstrate how uncertainty on clinical outcomes and safety risks are managed post-marketing. Results were pooled per jurisdiction to reveal patterns per regulatory authority.

\section{Results}

\section{Characteristics of regulatory assessments}

In total, 18 assessment procedures were included, seven in the US, nine in the EU and two in Japan (Table I). Most products were cell-based therapies (CTs; including device-combined therapies; $\mathrm{n}=12 / 18$ ). In vivo and ex vivo gene therapies (GTs) were exclusively approved in the US and EU. Provenge, Imlygic and MACI 
Table I. Overview of included products.

\begin{tabular}{|c|c|c|c|c|c|c|}
\hline & Product & $\begin{array}{c}\text { Year of } \\
\text { approval }\end{array}$ & $\begin{array}{l}\text { Approval } \\
\text { pathway }\end{array}$ & Product description & Therapeutic area ${ }^{a}$ & $\begin{array}{c}\text { Orphan } \\
\text { drug }\end{array}$ \\
\hline \multirow[t]{7}{*}{ US } & Provenge & 2010 & Fast track & $\begin{array}{l}\text { Autologous peripheral blood } \\
\text { mononuclear cells }\end{array}$ & Prostate cancer & $\mathrm{N}$ \\
\hline & Laviv & 2011 & Standard & $\begin{array}{l}\text { Autologous cultured } \\
\text { fibroblasts }\end{array}$ & $\begin{array}{l}\text { Moderate to severe nasolabial fold } \\
\text { wrinkles }\end{array}$ & $\mathrm{N}$ \\
\hline & Gintuit & 2012 & Standard & $\begin{array}{l}\text { Allogeneic cultured } \\
\text { keratinocytes and fibroblasts } \\
\text { in bovine collagen }\end{array}$ & Mucogingival conditions & $\mathrm{N}$ \\
\hline & Imlygic & 2015 & Fast track & $\begin{array}{l}\text { Genetically modified oncolytic } \\
\text { viral therapy }\end{array}$ & $\begin{array}{l}\text { Lesions in patients with } \\
\text { melanoma }\end{array}$ & $\mathrm{Y}$ \\
\hline & MACI & 2016 & Standard & $\begin{array}{l}\text { Autologous cultured } \\
\text { chondrocytes on a porcine } \\
\text { collagen membrane }\end{array}$ & Cartilage defects of the knee & $\mathrm{N}$ \\
\hline & Kymriah & 2017 & Standard (BTD) & $\begin{array}{l}\text { Genetically modified } \\
\text { autologous T-cell } \\
\text { immunotherapy }\end{array}$ & $\begin{array}{l}\text { B-cell precursor acute } \\
\text { lymphoblastic leukemia }\end{array}$ & $\mathrm{Y}$ \\
\hline & Yescarta & 2017 & Standard (BTD) & $\begin{array}{l}\text { Genetically modified } \\
\text { autologous T-cell } \\
\text { immunotherapy }\end{array}$ & $\begin{array}{l}\text { Relapsed or refractory large B-cell } \\
\text { lymphoma }\end{array}$ & $\mathrm{Y}$ \\
\hline \multirow[t]{9}{*}{ EU } & ChondroCelect & 2009 & Standard & Autologous cartilage cells & Cartilage defects of the knee & $\mathrm{N}$ \\
\hline & Glybera & 2012 & $\begin{array}{l}\text { Approval under } \\
\text { exceptional } \\
\text { circumstances }\end{array}$ & $\begin{array}{l}\text { Adeno-associated viral vector } \\
\text { for gene delivery }\end{array}$ & $\begin{array}{l}\text { Familial lipoprotein lipase } \\
\text { deficiency }\end{array}$ & $\mathrm{Y}$ \\
\hline & MACI & 2013 & Standard & $\begin{array}{l}\text { Matrix applied characterized } \\
\text { autologous cultured } \\
\text { chondrocytes }\end{array}$ & Cartilage defects of the knee & $\mathrm{N}$ \\
\hline & Provenge & 2013 & Standard & $\begin{array}{l}\text { Autologous peripheral blood } \\
\text { mononuclear cells }\end{array}$ & Prostate cancer & $\mathrm{N}$ \\
\hline & Imlygic & 2015 & Standard & $\begin{array}{l}\text { Genetically modified oncolytic } \\
\text { viral therapy }\end{array}$ & Melanoma & $\mathrm{N}$ \\
\hline & Holoclar & 2015 & Conditional & $\begin{array}{l}\text { Autologous human corneal } \\
\text { epithelial cells containing } \\
\text { stem cells }\end{array}$ & Corneal lesions & $\mathrm{Y}$ \\
\hline & Strimvelis & 2016 & Standard & $\begin{array}{l}\text { Autologous } \\
\text { CD } 34+\text { transduced cells } \\
\text { with retroviral vector }\end{array}$ & $\begin{array}{l}\text { Adenosine deaminase } \\
\text { deficiency (ADA-SCID) }\end{array}$ & $\mathrm{Y}$ \\
\hline & Zalmoxis & 2016 & Conditional & $\begin{array}{l}\text { Allogeneic } \mathrm{T} \text { cells genetically } \\
\text { modified with retroviral } \\
\text { vector }\end{array}$ & $\begin{array}{l}\text { Adjunctive treatment in } \\
\text { haploidentical hematopoietic } \\
\text { stem cell transplantation of } \\
\text { adult patients with high-risk } \\
\text { hematologic malignancies }\end{array}$ & $\mathrm{Y}$ \\
\hline & Spherox & 2017 & Standard & $\begin{array}{l}\text { Spheroids of human } \\
\text { autologous matrix- } \\
\text { associated chondrocytes }\end{array}$ & Cartilage defects of the knee & $\mathrm{N}$ \\
\hline \multirow[t]{2}{*}{ Japan } & Temcell & 2015 & Standard & $\begin{array}{l}\text { Allogeneic bone marrow- } \\
\text { derived mesenchymal } \\
\text { stem cells }\end{array}$ & GvHD & $\mathrm{Y}$ \\
\hline & Heartsheet & 2015 & Conditional & $\begin{array}{l}\text { Autologous skeletal myoblast- } \\
\text { derived cell sheet }\end{array}$ & $\begin{array}{l}\text { Severe heart failure (ischemic } \\
\text { heart disease) }\end{array}$ & $\mathrm{N}$ \\
\hline
\end{tabular}

BTD, Breakthrough Therapy Designation; GvHD, Graft-versus-Host Disease; N, no; Y, yes.

${ }^{\mathrm{a}}$ Based on indication of approved label.

were approved in both the US and EU. Other GCTs were exclusively marketed in the US, Japan or EU.

Most CTs originate from autologous starting material ( $\mathrm{n}=12 / 18$; Table II). More detailed product characteristics vary substantially, for example, cellular starting material consists of either antigen-presenting cells, differentiated tissue cells, lymphocytes or stem cells. GTs include both ex vivo and in vivo products with specific vectors (not shown).
A large proportion of approvals were granted for oncology $(n=7 / 18)$ and cartilage defects products $(n=4 / 18)$. A substantial amount $(n=7 / 9)$ of EU products targets indications that were considered severely debilitating or life-threatening. Multiple US ( $n=3 / 7$ ) and EU products $(n=4 / 9)$ were designated as orphan drugs, but lack of available alternative treatment for these products was mostly evident in the EU $(n=4 / 9)$. Targeted indications were also considered 
Table II. Summary of characteristics of regulatory assessment procedures per jurisdiction (n).

\begin{tabular}{|c|c|c|c|c|}
\hline Variable & $\begin{array}{l}\text { US } \\
(\mathrm{n}=7)\end{array}$ & $\begin{array}{c}\mathrm{EU} \\
(\mathrm{n}=9)\end{array}$ & $\begin{array}{l}\text { Japan } \\
(\mathrm{n}=2)\end{array}$ & $\begin{array}{c}\text { Total } \\
(\mathrm{n}=18)\end{array}$ \\
\hline \multicolumn{5}{|l|}{ Product type } \\
\hline \multicolumn{5}{|l|}{ Product profile } \\
\hline Gene therapy & 3 & 3 & 0 & 6 \\
\hline Cell therapy & 2 & 4 & 2 & 8 \\
\hline Combination therapies & 2 & 2 & 0 & 4 \\
\hline \multicolumn{5}{|l|}{$\begin{array}{l}\text { Starting material } \\
\text { cell-based therapy }\end{array}$} \\
\hline Autologous & 5 & 6 & 1 & 12 \\
\hline Allogeneic & 1 & 1 & 1 & 3 \\
\hline \multicolumn{5}{|l|}{ Target population } \\
\hline Lack of alternative therapy & 1 & 4 & 0 & 5 \\
\hline Orphan designation & 3 & 4 & 1 & 8 \\
\hline Severe disease & 5 & 7 & 2 & 14 \\
\hline \multicolumn{5}{|l|}{ Scientific evidence } \\
\hline $\begin{array}{l}\text { Randomized clinical trial/ } \\
\mathrm{Ph} 3 / \text { comparator }\end{array}$ & 5 & 5 & 0 & 10 \\
\hline Blinded pivotal trials & 2 & 1 & 0 & 3 \\
\hline $\begin{array}{l}\text { Clinically relevant primary } \\
\text { endpoint(s) }\end{array}$ & 7 & 9 & 1 & 17 \\
\hline $\begin{array}{l}\text { Clinically relevant } \\
\text { secondary endpoint(s) }\end{array}$ & 5 & 5 & 1 & 11 \\
\hline $\begin{array}{l}\text { Total no. of patients in } \\
\text { pivotal trial }(\mathrm{s})^{\mathrm{a}}\end{array}$ & 255 & 179 & 16 & na \\
\hline $\begin{array}{l}\text { Significant outcome } \\
\text { primary endpoint }\end{array}$ & 7 & 7 & 0 & 14 \\
\hline $\begin{array}{l}\text { Significant outcome } \\
\text { secondary endpoint }\end{array}$ & 2 & 4 & 0 & 6 \\
\hline Added clinical benefit & 4 & 4 & 0 & 8 \\
\hline \multicolumn{5}{|l|}{ Regulatory process } \\
\hline $\begin{array}{l}\text { Expedited/adaptive } \\
\text { pathway }\end{array}$ & 4 & 3 & 1 & 8 \\
\hline
\end{tabular}

na, not applicable.

${ }^{a}$ Mean no. of patients included in pivotal trial, including all study arms.

life-threatening in Japan ( $n=2 / 2)$, yet alternative treatment was not lacking $(\mathrm{n}=0 / 2)$. One GCT was designated an orphan drug (Table II).

The level of scientific evidence is comparable between the US and EU (Table II). A significant efficacy outcome on primary endpoint was demonstrated for all US $(n=7 / 7)$ and most EU $(n=7 / 9)$ assessments, whereas in Japan non-significant trends of efficacy were sufficient for approval. An added clinical benefit over standard treatment was demonstrated in pivotal trials for only two products (MACI [EU/ US], Gintuit [US]), but most trial designs lacked an active comparator or other standard therapy arm (US: $n=5 / 7 ;$ EU: $n=6 / 9$; Japan: $n=2 / 2$ ). Yet, all EU and one US orphan GCTs were considered to have added clinical benefit because alternative treatment is lacking $(\mathrm{n}=5 / 8)$. Pivotal trial design was most robust in the US for products approved before 2017, illustrated by exclusive approval based on randomized controlled trial (RCT) design (US: $\mathrm{n}=5 / 7$ ), compared with the EU $(n=5 / 9)$ and Japan $(n=0 / 2)$. Other non-randomized single-arm trial designs were accepted for two recent approvals in the US, three EU orphan drugs and all Japanese GCTs. Observational study design was used for one EU orphan GCT that was already previously available in some EU Member States. Furthermore, more patients were included in pivotal trials in the US ( $\mu=255$; range, 68-512) compared with the EU ( $\mu=179$; range, 12-512) and Japan ( $\mu=16$; range, $7-25$ ).

Approximately half of all products gained standard approval without expedited designations $(n=10 /$ 18), whereas others were approved under various expedited pathways and adaptive pathways (US: $n=4 /$ 7 ; JP: $\mathrm{n}=1 / 2$; EU: $\mathrm{n}=3 / 8$; Tables I-II, for definition see Supplementary Table 1). Overall, we observed less robust evidence for orphan drugs and approval under expedited or adaptive pathways, indicated by less RCTs, less significant efficacy outcomes and lower number of patients. Results indicated no differences between evidentiary support for gene- versus cellbased products (not shown).

\section{Benefit/risk assessments}

Regulatory assessment of scientific evidence was associated with considerable uncertainty in all jurisdictions. Uncertainties were often a result of suboptimal study design characteristics, including open label or single-arm design, change of primary endpoints, uncertain clinical relevance of endpoints, cross-study comparisons, retrospective data collection, use of historical controls and lack of biomarkers. Together with scarce technological and clinical experience these suboptimal study designs lead to limitations in the interpretation of efficacy and safety outcomes. Results indicate that regulatory authorities accept varying levels of uncertainty and safety risks for approval, taking different combinations of non-evidentiary factors into consideration. For many products, unmet medical need was considered to accept uncertainties and safety risks ( $\mathrm{n}=9 / 18)$, which was mostly evident in the EU and Japan (Table III).

The PMDA accepted limited evidence of efficacy and uncertain risks of severe adverse events for approval, considering the severity of targeted diseases and poor prognosis of patients with exhausted treatment options. Heartsheet was conditionally approved as a last resort treatment option, despite the highly uncertain clinical benefit. Temcell was approved as second-line treatment due to the observed trend of clinical benefit and otherwise poor prognosis (Table III). Furthermore, post-marketing pharmaceutical product development (i.e., acknowledging sterility issues and allowing verification of in-process specifications based on cumulative clinical data) was accepted under Japanese legislation for GCTs [21,22]. 
Table III. Representation of regulatory considerations for approval.

\begin{tabular}{|c|c|c|c|c|c|c|c|c|c|}
\hline & \multirow[b]{2}{*}{ Product } & \multicolumn{4}{|c|}{ Considerations for approval } & \multirow{2}{*}{$\begin{array}{c}\text { Outcomes } \\
\text { Restricted } \\
\text { labeling }\end{array}$} & \multicolumn{3}{|c|}{ Post-marketing study obligations } \\
\hline & & $\begin{array}{l}\text { Study } \\
\text { design }\end{array}$ & $\begin{array}{l}\text { Clinical } \\
\text { benefit }\end{array}$ & $\begin{array}{l}\text { Safety } \\
\text { profile }\end{array}$ & $\begin{array}{c}\text { Unmet } \\
\text { medical need }\end{array}$ & & Quality & Efficacy & Safety \\
\hline \multirow[t]{7}{*}{ US } & Laviv & $\Delta$ & $\Delta$ & $\Delta$ & $\square$ & [ & & & $\square$ \\
\hline & Gintuit & $\Delta$ & $\mathbf{\square}$ & $\mathbf{\square}$ & $\square$ & $\mathbf{\square}$ & $\mathbf{\square}$ & $\mathbf{\square}$ & $\mathbf{\square}$ \\
\hline & MACI & $\mathbf{\square}$ & $\mathbf{\square}$ & $\mathbf{\square}$ & $\square$ & $\Delta$ & $\mathbf{\square}$ & $\mathbf{\square}$ & $\mathbf{\square}$ \\
\hline & Imlygic & $\square$ & $\Delta$ & $\mathbf{\square}$ & $\mathbf{\square}$ & $\mathbf{\square}$ & & & $\mathbf{\square}$ \\
\hline & Provenge & $\Delta$ & $\mathbf{\square}$ & $\Delta$ & $\Delta$ & $\mathbf{\square}$ & & & $\square \Delta$ \\
\hline & Kymriah & $\mathbf{\square}$ & $\mathbf{\square}$ & $\square$ & $\Delta$ & $\square$ & $\Delta$ & & $\Delta$ \\
\hline & Yescarta & $\Delta$ & $\mathbf{\square}$ & $\square$ & $\mathbf{\square}$ & $\mathbf{\square}$ & & & $\square \Delta$ \\
\hline \multirow[t]{9}{*}{ EU } & ChondroCelect & $\square$ & $\mathbf{\square}$ & $\mathbf{\square}$ & $\square$ & $\mathbf{\square}$ & $\Delta$ & $\Delta \boldsymbol{\square}$ & $\Delta$ \\
\hline & Imlygic & $\Delta$ & $\Delta$ & $\Delta$ & $\Delta$ & $\mathbf{\square}$ & & $\mathbf{\square}$ & $\square \mathbf{\square}$ \\
\hline & MACI & $\mathbf{\square}$ & $\mathbf{\square}$ & $\square$ & $\square$ & $\Delta$ & & $\mathbf{\square}$ & 口 \\
\hline & Provenge & $\Delta$ & $\boldsymbol{\square}$ & $\Delta$ & $\mathbf{\square}$ & $\mathbf{\square}$ & $\boldsymbol{\square}$ & $\mathbf{\square}$ & $\square \Delta$ \\
\hline & Strimvelis & $\Delta$ & $\mathbf{\square}$ & $\square$ & $\mathbf{\square}$ & $\square$ & & $\square \Delta$ & $\square \Delta$ \\
\hline & Spherox & $\Delta$ & 口 & $\boldsymbol{\square}$ & $\square$ & $\mathbf{\square}$ & $\mathbf{\square}$ & $\mathbf{\square}$ & 口 \\
\hline & Holoclar & $\Delta$ & $\mathbf{\square}$ & $\square$ & $\boldsymbol{\square}$ & $\Delta$ & $\mathbf{\square}$ & $\square \mathbf{\square}$ & $\square \mathbf{\square}$ \\
\hline & Zalmoxis & $\Delta$ & $\Delta$ & $\mathbf{\square}$ & $\mathbf{\square}$ & $\square$ & & $\square \Delta \mathbf{\square}$ & $\square \Delta \square$ \\
\hline & Glybera & $\Delta$ & $\square$ & $\square$ & $\mathbf{\square}$ & $\mathbf{\square}$ & $\mathbf{\square}$ & 口 & $\square \mathbf{\square}$ \\
\hline \multirow[t]{2}{*}{ JP } & Temcell & $\square$ & $\Delta$ & $\square$ & $\square$ & $\mathbf{\square}$ & & $\Delta$ & $\Delta$ \\
\hline & Heartsheet & $\square$ & $\square$ & $\square$ & घ & a & a & $\mathbf{a}$ & 口 \\
\hline
\end{tabular}

Italic $=$ expedited/adaptive pathway, JP = Japan

Study design (pivotal trial): $\square=$ limitations for evaluation clinical data, acceptable, $\Delta=$ uncertainty/bias due to design, acceptable, - satisfactory.

Clinical benefit: $\square=$ limited indication of efficacy, $\Delta=$ possible benefit [in subgroup], $\mathbf{\square}=$ benefit, $\square=$ substantial benefit.

Safety profile: $\square$ = identified risks manageable, clinically acceptable, $\Delta=$ relatively well-tolerated, acceptable, $\square=$ acceptable/balanced safety profile.

Unmet medical needs: $\square=$ not taken into consideration, $\Delta$ = acknowledged, decision based on data, $\mathbf{\square}=$ taken into consideration for benefit/risk. Restricted labeling: $\square=$ no, $\Delta=$ minor label adjustment, $\mathbf{\square}=$ patient subgroup, $\mathbf{\square}=$ change of indication.

Post-marketing study obligations. Quality: $\Delta=$ minor follow up, $\mathbf{\square}=$ post-marketing validation. Efficacy \& safety: $\square=$ registry, $\Delta=$ observational study, $\mathbf{\square}=$ clinical trial.

Compared with Japan, submitted evidence in the EU was more robust. Nevertheless, many uncertainties were unresolved at approval. Non-significant indications of clinical benefit from non-randomized trials were accepted for approval of orphan GCTs that target severe indications without available alternative treatment, under adaptive pathways (Table III). For standard approvals, significant efficacy outcomes were demonstrated, which weighed heavily to reach positive opinions. However, suboptimal study characteristics (e.g., non-validated endpoints, no active comparator arm) and subsequent uncertainties on benefits were evident but considered acceptable, taking into account a balanced safety profile, or substantial benefits for indications with an unmet medical need. Safety profiles were considered manageable despite uncertainty around severe adverse events, or adverse events were deemed to be relatively well-tolerated compared with alternative treatment (oncology) (Table III).

In contrast to a focus on benefits and unmet medical needs in the EU, discussions for standard US approvals without expedited designations (Laviv, Gintuit) revolved more around uncertainty of safety risks because of the non-severe indications. Relatively robust study design and benefits were interpreted as uncertain by the FDA, however, these were ulti- mately accepted (Laviv) or resolved by Advisory Committee input (Gintuit). The study design and benefit/risk profile of MACI did not raise any concerns (Table III).

Imlygic and Provenge were approved in the US based on the same scientific evidence that was later submitted to the EMA. Regulatory assessments and outcome for Imlygic differed between the FDA and EMA, and other factors were considered to accept uncertainties. The invalidated primary endpoint and subsequent uncertain benefits were considered insufficient for approval by the FDA. However, clinical relevance was considered established due to patient reports of cosmetic and psychological benefits. To reflect this benefit, the FDA changed the label to treatment of lesions. In contrast, the EMA considered clinical benefit for melanoma established for a subgroup of patients, based on the same evidence. For Provenge, the benefit/risk assessment was comparable between the FDA and EMA (Table III) after consistent manufacturing was demonstrated in the EU. Substantially improved survival for a fatal disease outweighed the risk of severe adverse events for Provenge. For MACI benefits and risks were deemed satisfactory upon approval by both the EMA and the FDA. 
The recent approval of two chimeric antigen receptor T-cell (CAR-T) products (Kymriah, Yescarta) indicates different considerations in FDA decisionmaking compared with earlier approvals. Considering the substantial clinical benefit demonstrated for Kymriah, the FDA accepted severe safety risks (e.g., cytokine release syndrome and neurotoxicity) under conditions of enhanced risk management (Risk Evaluation and Mitigation Strategies [REMS]). The uncertainties related to the clinical benefit due to trial design and similar safety concerns for Yescarta were accepted considering the unmet medical need, together with REMS.

\section{Post-marketing risk management and collection of confirmatory evidence}

A wide range of post-marketing strategies to manage uncertainties and safety risks were observed in all jurisdictions, including safety risk surveillance, restricted labelling, risk minimization measures (e.g., boxed warnings, training material) and obligations to further develop quality and to conduct studies to confirm clinical outcomes and/or to manage long-term uncertainties. All regulatory authorities chose to restrict the label to specific patient groups as a result of uncertainties around clinical benefit $(n=12 / 18)$. However, in Japan and the EU post-marketing study obligations spread across quality, efficacy and safety aspects, whereas there is a general focus on safety in the US (Table III).

In Japan, follow-up is required for all patients, either via a survey after standard approval or an all-case surveillance evaluation during time-limited conditional approval. For the latter, in-process specifications also need to be confirmed based on cumulative clinical experience. In the EU, approvals are accompanied with substantial post-marketing study obligations compared with Japan and the US. Registries are required for products with uncertain risks of severe adverse events (e.g., tumorigenicity) $(n=6 / 9)$, including requests to collect long-term or confirmatory data in observational studies. Clinical trials to provide confirmatory evidence were requested for all but one product. Release specifications need to be further developed for four products in the EU. In the US, study obligations mainly focused on management of safety risks through clinical studies and registries. Few clinical trials were requested to confirm efficacy. The FDA allowed further quality development for three products (Table III).

\section{Discussion}

In this article we compared regulatory assessment and decision-making for GCT approval in the US, EU and Japan. Despite a limited cohort size, our results suggest that willingness to accept GCT-associated uncertainties and safety risks is highest in Japan, followed by the EU and US. Considerations of the target population and unmet medical needs are more prominent in Japanese and EU benefit/risk assessments, as well as post-marketing management of uncertainties. In the US, considerations for two recent approvals of CAR-T products suggest a shift toward a more permissive approach by the FDA because previous approvals revealed a relatively low willingness to accept uncertainty and safety risks upon approval in the US. However, there is less emphasis on post-marketing collection of confirmatory evidence in the US compared with the EU and Japan.

The results from our study underline the effects of implemented legislation for GCTs in the EU and Japan over the last 10 years [13]. Moreover, the substantial use of adaptive pathways and subsequent approval based on non-confirmatory evidence, combined with a relatively large emphasis on unmet medical needs and post-marketing data collection, indicate a trend toward an adaptive approach to licensing or a life cycle approach $[23,24]$. In Japan, regulations moved toward a legislative model of adaptive licensing, enabling conditional approval based on early development data since $2014[21,25,26]$. These regulatory standards facilitate the development of innovative GCT technologies and early access, although many quality, efficacy and safety uncertainties may be unresolved at approval. Although findings are based on small numbers, they are in line with the legislative approach for GCT approval in Japan. If this trend continues, it is critical to prevent off-label use and ensure correct administration methods when more GCTs reach the Japanese market, particularly because global GCT development may become skewed toward Japan due to regulatory advantages [13]. The Japanese approach for approval of GCTs is in stark contrast with stringent decision-making for approval of other medicines in Japan [27]. Therefore, it is recommended to carefully monitor and evaluate the impact of GCT legislation to optimize its effects on public health in due time.

In the EU, half of the approved GCTs represent niche products, marked by their orphan drug designation and exclusive approval in Europe. Lack of available treatment and small patient populations explain observations of regulatory willingness to accept uncertainty and non-confirmatory evidence for orphan GCT approval $[28,29]$. However, our findings confirm earlier observations that EU regulators are prepared to have an adaptive approach for GCT approval in general. Early indications of clinical benefit and unmet medical need considerations currently outweigh uncertainties and safety risks across therapeutic areas $[1,3,5]$, under conditions of substantial post-marketing 
risk management and data collection. This approach extends to non-orphan GCTs, thereby creating space to facilitate GCT innovation. However, it is important that authorities deliberately consider adaptive pathways for GCTs in early development phases to avoid becoming a 'rescue option' for substandard applications [20] and to prevent inappropriate use of orphan drug designation [30]. An inclusive approach to adaptive licensing is also warranted to take patient needs into account and to prevent market access issues and negative reimbursement evaluations [31,32]. Early multilateral scientific advice with regulatory agencies and payers is one possible solution to ensure patient access to innovative medicines for which adaptive licensing is considered necessary [33].

For approvals before 2017, US regulators appear to have had a relatively risk-averse approach for GCT approval compared with their Japanese and EU counterparts, which is in line with an earlier report [34]. Three of the marketed products in the US are also marketed in the EU, whereas the other US approvals are relatively less innovative compared with products exclusively marketed in Japan and the EU: GCTs that were developed for cosmetic and periodontal purposes. However, the recent approval of two CAR-T products could indicate a tipping point in regulatory decision-making in the US. This observation is in line with recent reforms in the US [23]. Newly implemented regulatory designations that facilitate the development of GCTs and other medicines (i.e., Breakthrough Therapy Designations) were evident in the CAR-T assessments and may also impact future applications with the potential of substantially improved clinical outcomes [23]. In addition, the implementation of the $21^{\text {st }}$ Century act provides another designation to expedite GCT approval specifically, the Regenerative Medicine Advanced Therapy (RMAT) Designation [35]. RMAT Designation provides similar benefits for developers as the Breakthrough Therapy Designation, including discussion of possibilities to use surrogate endpoints. In contrast to Breakthrough Therapy Designation, RMAT Designation supports eligibility for accelerate approval. Furthermore, eligibility for RMAT Designation does not require preliminary clinical evidence that indicates a substantial improvement on clinically relevant endpoints. Instead, clinical evidence needs to indicate the potential to address unmet medical needs [36]. This facilitated approach is indicative of a regulatory convergence for GCT licensing across regions and an increasingly leveled playing field for GCT regulatory evaluation.

Despite a converging trend toward expedited and adaptive licensing in the GCT field, eligibility criteria for jurisdiction-specific pathways and the corresponding requirements for approval are different. These differences are a natural consequence of the still small-scale nature of GCT development and the corresponding emergence of regulatory oversight in different governance structures and clinical practice [13]. However, applications and approvals of breakthrough GCT technologies and other innovative GCTs are likely to increase in the near future considering the vast GCT clinical pipeline [37-41]. More global development and registration strategies are likely to emerge in the future with a high probability of using expedited and adaptive pathways across jurisdictions, including other pathways not discussed here, such as the EU PRIME scheme and the Japanese Sakigake strategy $[23,42]$. Parallel scientific advice meetings with multiple regulatory agencies could clarify which evidentiary requirements are needed for global registration strategies. Furthermore, regulatory agencies are holding joint meetings and other forums to harmonize regulatory strategies for GCT approval [43]. However, early access to GCTs is ultimately dependent on payment structures, such as national reimbursement schemes, rather than adaptive approaches to licensing. Future approaches to the integration of post-marketing risk management and regional payment structures may differ substantially between jurisdictions [23].

Accepting substantial uncertainties and safety risks for GCT approval calls for long-term post-marketing surveillance and enforcement measures [13], not just to monitor uncertainties that are noted at point of approval but also new uncertainties that arise after approval [44]. The success of the Japanese legislation for GCTs may depend on appropriate postmarketing surveillance and data collection [45], a role in which the PMDA has limited experience [46]. Registries facilitate observational studies, however, designs may not always be suitable to provide confirmatory data. Thus, it is important that designs for postmarketing data collection match with the purpose of those studies [47]. Furthermore, the amount of postmarketing study obligations in the EU shown here and elsewhere [48] imposes considerable challenges for patient recruitment and long-term follow-up, which may lead to delays to complete post-marketing studies. In contrast, post-marketing study obligations focus on long-term management of safety risks instead of postmarketing studies to provide confirmatory data in the US. There appears to be less focus on post-marketing studies in the US in general, as indicated by earlier reports of limited enforcement by US authorities to complete such studies $[49,50]$. Thus, the trend of a life cycle approach for GCTs is less evident compared with Japan and the EU. Striking a suitable balance between approval and post-marketing study obligations for GCTs could become the largest challenge for regulatory agencies around the world. 
Trial design challenges hinder GCT approval [5], which has also been shown for promising candidates such as CAR-T [51]. It is a complex task to incorporate benefits, risks and sources of uncertainties into benefit-risk assessments, which is further complicated when endpoints differ between patient populations or over time, or when data is pooled from various studies [52]. Fields that are moving toward personalized medicine or treatment for specific subpopulations (e.g., oncology) are searching for solutions such as biomarker-driven designs [53]. It is vital that GCT developers invest in their clinical trial methodologies, consider study design challenges during early development stages and possibly learn from advances made in other fields.

In conclusion, willingness to accept uncertainty and safety risks for GCT approval is currently evident for all three regulatory authorities. To reduce uncertainties, developers and regulators need to find ways early in development to improve study designs [54], acknowledging the inherit challenges of target populations and GCT characteristics. Furthermore, regulatory experience and future GCT generations are expected to rapidly co-evolve in the coming years. Our results indicate that these advances will mostly take place within adaptive approaches to licensing, under regulatory standards of varying expedited and adaptive pathways [23]. Early access and long-term uncertainties urge authorities to cautiously consider and enforce appropriate post-marketing risk management and collection of confirmatory evidence. Thus, knowledge sharing between agencies and opportunity for parallel scientific advice need to be further strengthened to facilitate clinical development and suitable regulatory standards throughout the GCT life cycle $[13,43]$.

\section{Acknowledgments}

Disclosure of interests: All authors declare no conflict of interest, no support from any organization for the submitted work, no financial relationships with any organizations that might have an interest in the submitted work in the previous 3 years or other relationships or activities that could appear to have influenced the submitted work.

\section{References}

[1] Fischbach MA, Bluestone JA, Lim WA. Cell-based therapeutics: the next pillar of medicine. Sci Transl Med 2013;5:179ps7.

[2] Wirth T, Parker N, Ylä-Herttuala S. History of gene therapy. Gene 2013;525:162-9.

[3] Kumar SR, Markusic DM, Biswas M, High KA, Herzog RW. Clinical development of gene therapy: results and lessons from recent successes. Mol Ther - Methods Clin Dev 2016;3: 16034.
[4] Brévignon-Dodin L, Singh P. ATMP in practice: towards a new industry landscape in tissue engineering. J Commer Biotechnol 2008;15:59-65.

[5] Schneider CK, Salmikangas P, Jilma B, Flamion B, Todorova LR, Paphitou A, et al. Challenges with advanced therapy medicinal products and how to meet them. Nat Rev Drug Discov 2010;9:195-201.

[6] Salmikangas P, Menezes-Ferreira M, Reischl I, Tsiftsoglou A, Kyselovic J, Borg JJ, et al. Manufacturing, characterization and control of cell-based medicinal products: challenging paradigms toward commercial use. Regen Med 2015;10:6578.

[7] Bravery CA, Carmen J, Fong T, Oprea W, Hoogendoorn KH, Woda J, et al. Potency assay development for cellular therapy products: an ISCT ${ }^{\star}$ review of the requirements and experiences in the industry. Cytotherapy 2013;15:9-19, e9.

[8] Pignatti F, Ashby D, Brass E, Eichler H-G, Frey P, Hillege $\mathrm{H}$, et al. Structured frameworks to increase the transparency of the assessment of benefits and risks of medicines: current status and possible future directions. Clin Pharmacol Ther 2015;98:522-33.

[9] Eichler H-G, Pignatti F, Flamion B, Leufkens H, Breckenridge A. Balancing early market access to new drugs with the need for benefit/risk data: a mounting dilemma. Nat Rev Drug Discov 2008;7:818-26.

[10] Tafuri G, Stolk P, Trotta F, Putzeist M, Leufkens HG, Laing RO, et al. How do the EMA and FDA decide which anticancer drugs make it to the market? A comparative qualitative study on decision makers' views. Ann Oncol 2014;25:265-9.

[11] Liberti L, Breckenridge A, Hoekman J, McAuslane N, Stolk P, Leufkens H. Factors related to drug approvals: predictors of outcome? Drug Discov Today 2017;22:937-46.

[12] Hauray B. From regulatory knowledge to regulatory decisions: the European evaluation of medicines. Minerva 2017;55:187208.

[13] Coppens DGM, De Bruin ML, Leufkens HGM, Hoekman J. Global regulatory differences for gene and cell based therapies: consequences and implications for patient access and therapeutic innovation. Clin Pharmacol Ther 2018; 103:120-7.

[14] Melchiorri D, Pani L, Gasparini P, Cossu G, Ancans J, Borg $\mathrm{JJ}$, et al. Regulatory evaluation of Glybera in Europe - two committees, one mission. Nat Rev Drug Discov 2013;12: 719.

[15] European Medicines Agency. European public assessment reports. Available from: http://www.ema.europa.eu/ ema/index.jsp?curl=/pages/medicines/landing/epar_search .jsp\&mid=WC0b01ac058001d124. Accessed $28 \mathrm{March}$ 2018.

[16] Pharmaceuticals and Medical Devices Agency. Review Reports: Regenerative Medical Products. Available from: http://www.pmda.go.jp/english/review-services/reviews/ approved-information/0004.html. Accessed $28 \mathrm{March}$ 2018.

[17] Food and Drug Administration. Approved Cellular and Gene Therapy Products. Available from: https://www.fda.gov/ BiologicsBloodVaccines/CellularGeneTherapyProducts/ ApprovedProducts/default.htm. Accessed 28 March 2018.

[18] Putzeist M, Mantel-Teeuwisse AK, Aronsson B, Rowland M, Gispen-de Wied CC, Vamvakas S, et al. Factors influencing non-approval of new drugs in Europe. Nat Rev Drug Discov 2012;11:903-4.

[19] Putzeist M, Mantel-Teeuwisse AK, Llinares J, Gispen-De Wied CC, Hoes AW, Leufkens HGM. EU marketing authorization review of orphan and non-orphan drugs does not differ. Drug Discov Today 2013;18:1001-6. 
[20] Hoekman J, Boon W, Bouvy J, Ebbers H, de Jong J, De Bruin $M$. Use of the conditional marketing authorization pathway for oncology medicines in Europe. Clin Pharmacol Ther 2015;98:534-41.

[21] Hara A, Sato D, Sahara Y. New governmental regulatory system for stem cell-based therapies in Japan. Ther Innov Regul Sci 2014;48:681-8.

[22] Azuma K. Regulatory landscape of regenerative medicine in Japan. Curr Stem Cell Rep 2015;1:118-28.

[23] Oye KA, Eichler HG, Hoos A, Mori Y, Mullin TM, Pearson $M$. Pharmaceuticals licensing and reimbursement in the European Union, United States, and Japan. Clin Pharmacol Ther 2016;100:626-32.

[24] Eichler H-G, Baird LG, Barker R, Bloechl-Daum B, Børlum-Kristensen F, Brown J, et al. From adaptive licensing to adaptive pathways: delivering a flexible life-span approach to bring new drugs to patients. Clin Pharmacol Ther 2015; 97:234-46.

[25] Konomi K, Tobita M, Kimura K, Sato D. New Japanese initiatives on stem cell therapies. Cell Stem Cell 2015;16:350 2.

[26] Okada K, Koike K, Sawa Y. Consideration of and expectations for the pharmaceuticals, medical devices and other therapeutic products act in Japan. Regen Ther 2015;1:80 3.

[27] Asada R, Shimizu S, Ono S, Ito T, Shimizu A, Yamaguchi $\mathrm{T}$. Analysis of new drugs whose clinical development and regulatory approval were hampered during their introduction in Japan. J Clin Pharm Ther 2013;38:309-13.

[28] Putzeist M, Heemstra HE, Garcia JL, Mantel-Teeuwisse AK, Gispen-De Wied CC, Hoes AW, et al. Determinants for successful marketing authorisation of orphan medicinal products in the EU. Drug Discov Today 2012;17:3528.

[29] Duijnhoven RG, Straus SMJM, Raine JM, Boer A, de Hoes AW, Bruin MLD. Number of patients studied prior to approval of new medicines: a database analysis. PLoS Med 2013;10: e1001407.

[30] Kesselheim AS, Treasure CL, Joffe S. Biomarker-defined subsets of common diseases: policy and economic implications of orphan drug act coverage. PLoS Med 2017; 14:e1002190.

[31] Abou-El-Enein M, Elsanhoury A, Reinke P. Overcoming challenges facing advanced therapies in the EU market. Cell Stem Cell 2016;19:293-7.

[32] Driscoll D, Farnia S, Kefalas P, Maziarz RT. Concise review: the high cost of high tech medicine: planning ahead for market access. Stem Cells Transl Med 2017;6:1723-9.

[33] Enzmann H. New trends and challenges in the European regulation of innovative medicines. Regul Toxicol Pharmacol 2016;80:314-20.

[34] Califf RM. Benefit-risk assessments at the us food and drug administration: finding the balance. JAMA 2017;317: 693-4.

[35] Kesselheim AS, Avorn J. New "21st Century Cures" Legislation: speed and ease vs science. JAMA 2017;317:5812.

[36] Food and Drug Administration. Expedited Programs for Regenerative Medicine Therapies for Serious Conditions: Draft Guidance for Industry; 2017. Available from: https:// www.fda.gov/downloads/biologicsbloodvaccines/ guidancecomplianceregulatoryinformation/guidances/ cellularandgenetherapy/ucm585414.pdf. Accessed 28 March 2018.

[37] Hanna E, Rémuzat C, Auquier P, Toumi M. Advanced therapy medicinal products: current and future perspectives. J Mark Access Health Policy; 2016. Available from: http://
www.ncbi.nlm.nih.gov/pmc/articles/PMC4846788/. Accessed 28 March 2018.

[38] de Wilde S, Guchelaar H-J, Zandvliet ML, Meij P. Clinical development of gene- and cell-based therapies: overview of the European landscape. Mol Ther Methods Clin Dev 2016;3:16073.

[39] Borán̆ T, Menezes-Ferreira M, Reischl I, Celis P, Ferry N, Gänsbacher B, et al. Clinical Development and Commercialization of Advanced Therapy Medicinal Products (ATMPs) in the EU: how are the product pipeline and regulatory framework evolving? Hum Gene Ther Clin Dev 2017;28:126-35.

[40] Ruffin M. BIO-Europe Spring: Promise of Cell \& Gene Therapy. BIO-Europe Spring 2016. Stockholm; 2016. Available from: https://alliancerm.org/sites/default/ files/Morrie_BES_2016_FINAL.pdf. Accessed 28 March 2018.

[41] Ruffin M, Werner M, Preti R. 2017 Cell \& Gene Therapies. State of the Industry Briefing. JP Morgan Biotech Showcase. San Francisco; 2017. Available from: https://alliancerm.org/ sites/default/files/ARM_SOTI_2017_FINAL_web_version _.pdf. Accessed 28 March 2018.

[42] Mullard A. PRIME time at the EMA. Nat Rev Drug Discov 2017;16:226-8.

[43] Milne C-P, Mittra J, Kojima N, Sugiyama D, Awatin J, Simmons G. Prospects for harmonizing regulatory science programs in europe, japan, and the united states to advance regenerative medicine. Ther Innov Regul Sci 2016;50:72433.

[44] Vermeer NS, Duijnhoven RG, Straus SMJM, Mantel-Teeuwisse AK, Arlett PR, Egberts ACG, et al. Risk management plans as a tool for proactive pharmacovigilance: a cohort study of newly approved drugs in Europe. Clin Pharmacol Ther 2014;96:723-31.

[45] Jokura Y, Yano K, Yamato M. A comparison of the new Japanese expedited approval legislation for regenerative medicine product with the existing systems of the United States and European Union. JTissue Eng Regen Med; 2017. Available from: http://onlinelibrary.wiley.com/doi/10.1002/ term.2428/abstract. Accessed 28 March 2018.

[46] van Schothorst M, Weeda J, Schiffers K, Oortwijn W, Hoekman J, Coppens D, et al. Study on the regulation of advanced therapies in selected jurisdictions. 20147306 RfS Chafea/2014/Health/24 - Final Report; 2016. Available from: http://ec.europa.eu/health/human-use/docs/20147306_rfs _chafea_2014_health_24_060516.pdf. Accessed 28 March 2018.

[47] Thorpe KE, Zwarenstein M, Oxman AD, Treweek S, Furberg CD, Altman DG, et al. A pragmatic-explanatory continuum indicator summary (PRECIS): a tool to help trial designers. J Clin Epidemiol 2009;62:464-75.

[48] Hoekman J, Klamer TT, Mantel-Teeuwisse AK, Leufkens HGM, De Bruin ML. Characteristics and follow-up of postmarketing studies of conditionally authorized medicines in the EU. Br J Clin Pharmacol 2016;82:21326.

[49] Pease AM, Krumholz HM, Downing NS, Aminawung JA, Shah ND, Ross JS. Postapproval studies of drugs initially approved by the FDA on the basis of limited evidence: systematic review. BMJ 2017;357:j1680.

[50] Willyard C. FDA's post-approval studies continue to suffer delays and setbacks. Nat Med 2014;20:1224-5.

[51] de Wilde S, Guchelaar H-J, Zandvliet ML, Meij P. Understanding clinical development of chimeric antigen receptor T cell therapies. Cytotherapy 2017;19:703-9.

[52] Mt-Isa S, Ouwens M, Robert V, Gebel M, Schacht A, Hirsch I. Structured Benefit-risk assessment: a review of key 
publications and initiatives on frameworks and methodologies. Pharm Stat 2016;15:324-32.

[53] Berry D. The brave new world of clinical cancer research: adaptive biomarker-driven trials integrating clinical practice with clinical research. Mol Oncol 2015;9:951-9.

[54] Brunner M, Jilma B. Development of Advanced Therapy Medicinal Products: A Case for Early Scientific Advice. In: Müller M, editor. Clinical Pharmacology: Current Topics and Case Studies. Springer International Publishing; 2016. p. 293-303. Available from: http://link.springer.com/ chapter/10.1007/978-3-319-27347-1_18. [Accessed 28 March 2018].

\section{Appendix: Supplementary material}

Supplementary data to this article can be found online at doi:10.1016/j.jcyt.2018.03.038. 